\title{
Rangeland Degradation Impacts on Vegetation Cover, Soil Properties and Ecosystem Functioning in an Arid and Semi-Arid Climate, South Africa
}

\author{
Hermias Cornelius van der Westhuizen1, Christiaan Cornelius du Preez ${ }^{2 *}$, Hendrik Andries Snyman ${ }^{3}$ \\ ${ }^{1}$ Free State Department of Agriculture and Rural Development, Glen, South Africa \\ ${ }^{2}$ Department of Soil, Crop and Climate Sciences, University of the Free State, Bloemfontein, South Africa \\ ${ }^{3}$ Department of Animal, Wildlife and Grassland Sciences, University of the Free State, Bloemfontein, South Africa \\ Email: *dpreezcc@ufs.ac.za
}

How to cite this paper: van der Westhuizen, H. C., du Preez, C. C., \& Snyman, H. A. (2022). Rangeland Degradation Impacts on Vegetation Cover, Soil Properties and Ecosystem Functioning in an Arid and Semi-Arid Climate, South Africa. Journal of Geoscience and Environment Protection, $10,10-32$.

https://doi.org/10.4236/gep.2022.102002

Received: December 13, 2021

Accepted: February 11, 2022

Published: February 14, 2022

Copyright $\odot 2022$ by author(s) and Scientific Research Publishing Inc. This work is licensed under the Creative Commons Attribution International License (CC BY 4.0).

http://creativecommons.org/licenses/by/4.0/

\begin{abstract}
The negative effect of soil erosion and soil compaction is well documented for the purpose of optimum rangeland functioning, while the impact of rangeland degradation on effective soil depth is seldom quantified. The aim of this study was to quantify the response of vegetation cover and soil properties, particularly effective soil depth and soil texture to rangeland degradation. Forty-one farms were sampled in the arid and semi-arid climate of South Africa. Within these farms, data was collected over a vegetation degradation gradient. Results showed a significant decline in relative basal cover $(94 \% \pm$ $15 \%$ to $39 \% \pm 17 \%)$ and soil depth $(90 \% \pm 14 \%$ to $73 \% \pm 24 \%)$ as rangeland degraded. Soil texture changes over the degradation gradients vary for different homogeneous vegetation types. Indications regarding the loss of a functioning rangeland ecosystem were also demonstrated, using objective long-term relations between rangeland conditions and grazing capacity. The study highlights the importance of sustainable rangeland management practices to reduce the loss in effective soil depth and to ensure the sustainable utilization of the rangeland ecosystem. These results can probably extrapolate to other arid and semi-arid rangelands worldwide.
\end{abstract}

\section{Keywords}

Rangeland Condition, Soil Degradation, Effective Soil Depth, Soil Erosion, Soil Compaction, Ecosystem Functioning

\section{Introduction}

There is no doubt that rangeland degradation affects the quality of soil and this 
might vary across different vegetation types, climatic conditions and soil types. Soil degradation on rangelands involves the decline in soil quality caused by unsustainable rangeland management practices. Soil quality degradation is a serious global environmental problem and may be exacerbated by rangeland degradation, desertification and climate change (Van der Westhuizen et al., 2020). According to Pimentel and Burgess (2013), the world has lost a third of its arable land in the past 40 years due to erosion (physical degradation) or pollution (chemical degradation), and according to Thompsell (2017), 40\% of the land in Africa is degraded. When the production potential of rangelands is overestimated, the subsequent overgrazing will lead to a decrease of palatable perennial plants in favor of less palatable, undesirable vegetation (Van der Westhuizen et al., 2005), while the vegetation cover, soil quality (Kotzé et al., 2020) and productivity of the rangeland will also decline. This causes permanent degradation of rangeland and soil quality, hampering the ability to sustain optimal livestock production which will have a negative impact on global food demand in future.

Soil depth is critical for optimal plant productivity (Kosmas et al., 1999). Any discontinuities in the soil profile, from layers of sand or gravel to bedrock, as well as soil compaction can physically limit root penetration (Snyman, 2009). Effective soil depth is also affected by a number of other factors with various scales that include inter alia parent material weathering, climate conditions, vegetation cover, topographical position, soil type as well as kind of land use and human activities (Boettinger et al., 1997; Zare et al., 2011; Abd-Elmabod et al., 2017). Soil depth can greatly influence the types of plants that can grow in soils. Deeper soils can usually provide more water and nutrients to plants than more shallow soils (Kotzé et al., 2020).

One of the important reasons for soil degradation on rangeland can be linked to the effect of animals on soil compaction (Jacobs, 1988; Kotzé et al., 2020). Animal tramping firstly leads to soil compaction, as well as a decline in soil structure of the topsoil (Euckert et al., 1978; Du Toit, 1986; Kotzé et al., 2020). This will lead to lower water infiltration and aeration (Pietola et al., 2005), increase of surface runoff, soil erosion and nutrient losses (Smith et al., 1990; Zhou et al., 2010). These effects enhance the soil resistance against root growth penetration (Schenk \& Jackson, 2002) and also have a negative impact on the survival rate of seedlings (Kinucan \& Smeins, 1992; Adams, 1996). It seems that soil compaction and stocking rate are linked as Chamane et al. (2017) found significantly higher soil compaction in short duration, high density grazing farms with a stocking rate of double the number of animal units, compared to low density grazing systems. These data were collected along fence line contrast between the different grazing systems in mesic grassland vegetation near Cedarville and Kokstad in South Africa. Kotzé et al. (2013) also found higher bulk densities in communal farms with a stocking rate of $4.3 \mathrm{ha} \cdot \mathrm{LSU}^{-1}$ compared with commercial farms with a stocking rate of $6.4 \mathrm{ha} \cdot \mathrm{LSU}^{-1}$, while the lowest bulk densities were found in a nature reserve with a stocking rate of $10.4 \mathrm{ha} \cdot \mathrm{LSU}^{-1}$, in a grass- 
land vegetation type near Thaba Nchu in South Africa. Animal tramping and soil compaction due to unsustainable rangeland practices can also lead to the breakdown of soil aggregates (Stavi et al., 2011; Teague et al., 2011; Kotzé et al., 2013). According to Zhou et al. (2020) soil aggregates, the basic unit of soil structure mediates many physical and chemical processes in soils, such as soil compaction, soil nutrient recycling, soil erosion, root penetration, and crop yield.

The effect of rangeland degradation on soil erosion is well documented in South Africa (Snyman, 2014). Soil loss from rangeland in arid and semi-arid areas can increase on the same soil from 0.4 to $2.6 \mathrm{t}^{\mathrm{h}} \mathrm{ha}^{-1} \cdot \mathrm{year}^{-1}$ as rangeland condition deteriorates and vegetation composition and cover change. The genesis of soil however, is very slow, and according to Scotney and McPhee (1991) soil loss (marginal values) from rangeland in southern Africa of 0.5 to $1.0 \mathrm{t} \cdot \mathrm{ha}^{-1} \cdot \mathrm{year}^{-1}$ is permissible.

Rangeland degradation and soil degradation are dependent on each other. The functioning of both the soil and the plant communities is crucial for the sustainability of the rangeland ecosystem. Rangeland conditions, as an indication of vegetation composition and cover, are usually employed to determine the current state of health of rangelands, whereby soil indicators such as the loss in effective soil depth and change in soil texture may have long-term impacts. With soil degradation research on rangelands, the focus is mainly on soil erosion and soil compaction, while less attention is given to effective soil depth and soil texture. Quantifying the response of effective soil depth and soil texture to rangeland conditions for arid and semi-arid climate, will contribute to a better understanding of the collapse of ecosystems' ability to sustain livestock production. By linking the loss in ecosystem services to rangeland condition and soil degradation, more sustainable animal performance recommendations can be made.

The challenge therefore lies in balancing soil degradation processes with the beneficial effects of the application of healthy rangeland management principles and conservation practices by ensuring that rangelands are in an optimal condition to ensure sustainable ecosystem functioning. Our hypothesis was that rangeland degradation over long periods enhances soil erosion and soil compaction, which leads to a decline in effective soil depth in arid and semi-arid environments. The aim of this study was therefore to investigate the effect of rangeland conditions on the decline in basal cover and soil properties, particularly effective soil depth and soil texture and to calculate the loss in ecosystem functioning across the arid and semi-arid climate of the Free State province, South Africa.

\section{Materials and Methods}

\subsection{Study Area}

The study area is located in the central, southern and western parts of the Free State province of South Africa (Figure 1) and includes an area of about 90,000 $\mathrm{km}^{2}$ (Latitude $27^{\circ} 55^{\prime} \mathrm{S}-30^{\circ} 40^{\prime} \mathrm{S}$, Longitude $24^{\circ} 10^{\prime} \mathrm{E}-27^{\circ} 45^{\prime} \mathrm{E}$ ). The area varies 


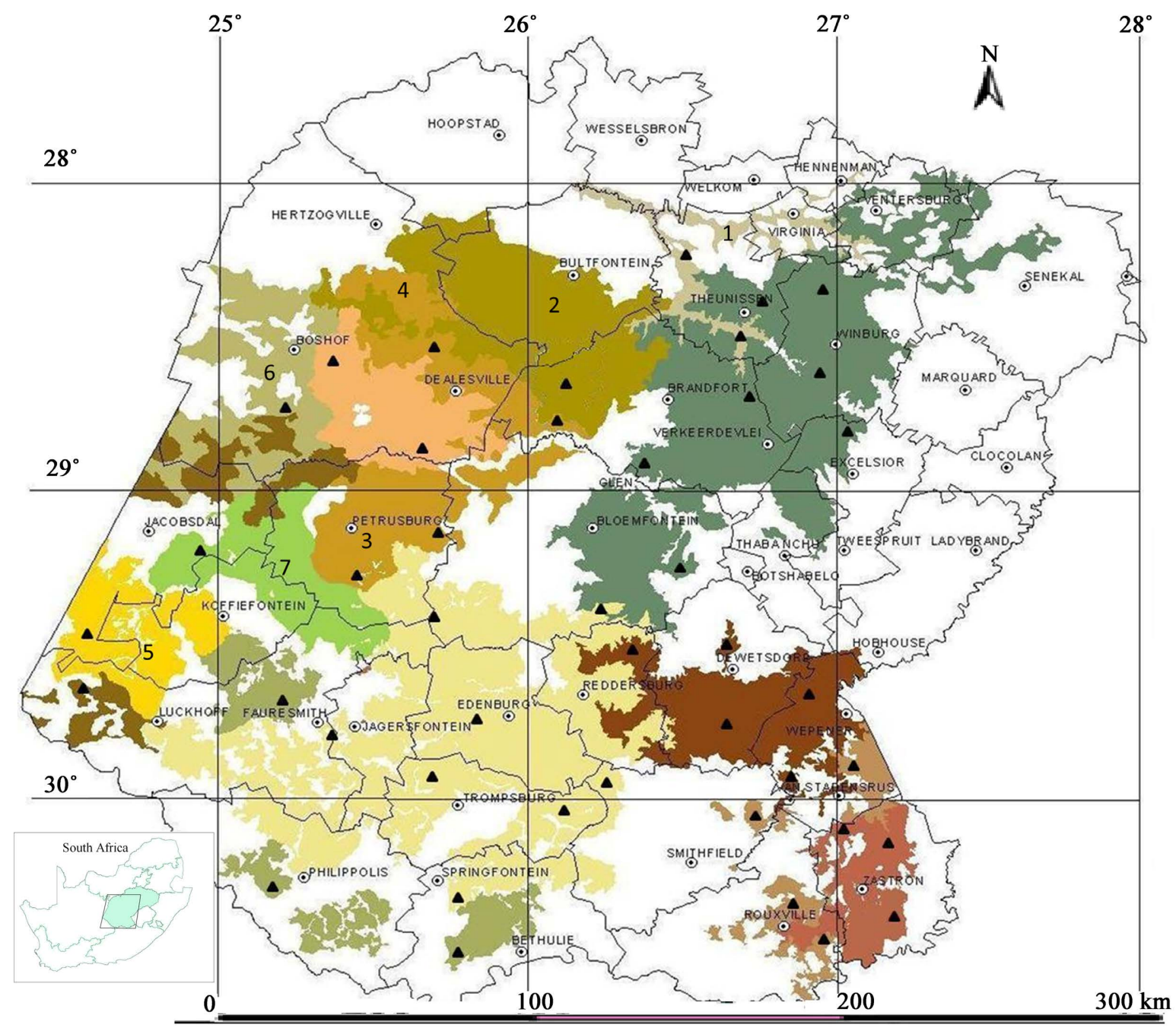

Figure 1. Study area with farms and relative homogenous vegetation communities in the Free State province, South Africa. (1-Panicum Grassland; 2-Themeda-Sporobolus Grassland; 3-Sandy vegetation south; 4-Sandy vegetation north; 5-Eragrostis grass-Karoid vegetation; 6-Open Parkland north and 7-Open Parkland south).

from $1650 \mathrm{~m}$ in the east to $1150 \mathrm{~m}$ above sea level in the west.

The vegetation was classified by Van der Westhuizen (2003) in sixteen different relative homogeneous vegetation communities, varying from the Grassland biome in the east to the Savannah biome in the north-west and the Nama-Karoo biome in the western parts according to the classification of Mucina and Rutherford (2006). Mean annual rainfall varies between $600 \mathrm{~mm}$ in the east to 300 $\mathrm{mm}$ in the west. Though major seasonal differences occur, $70 \%-80 \%$ of rain falls in summer from November to April. The different relative homogeneous vegetation communities were further divided into arid (average rainfall below $400 \mathrm{~mm}$ ) and semi-arid (average rainfall above $400 \mathrm{~mm}$ ) environments according to indications of Kotzé et al. (2020). The highest mean monthly maximum temperature of $29.7^{\circ} \mathrm{C}$ for summer occurs during January in the east, compared to $33.7^{\circ} \mathrm{C}$ in the west. The lowest mean monthly minimum temperature during winter varies from $-3.0^{\circ} \mathrm{C}$ in the east to $1.2^{\circ} \mathrm{C}$ in the west. Climate data and do- 
minant soil forms as classified by the Binomial System for South Africa (Macvicar et al., 1977), as well as the World Reference Base for Soil Resources (WRB, 2007) were used as indicated in Table 1 for a few selective homogeneous vegetation types.

\subsection{Sampling Sites}

Sites were collected on 41 farms evenly distributed over the study area. Three plots $(100 \mathrm{~m} \times 100 \mathrm{~m})$ were selected on every farm representing different rangeland conditions over a grazing gradient, starting near an artificial water point. To limit soil, slope and topography differences, plots were limited to areas representing the same ecotype (Trollope et al., 1990) within the same paddock on every farm.

The species composition of the herbaceous layer was determined on the basis of frequency of occurrence, using the wheel point apparatus (Tidmarsh \& Havenga, 1955) where nearest plant and basal cover strikes were recorded. Basal cover is defined by Trollope et al. (1990) as the area of ground covered by the living basal portions of plants. Effective soil depth was determined using an auger, where the depth was material which markedly restricts water as well as root penetration. Topsoil was also collected to a depth of $200 \mathrm{~mm}$ to determine texture classes.

\subsection{Experimental Techniques}

The botanical composition was used to determine rangeland conditions. Rangeland conditions were determined for every site using a degradation gradient technique which was previously developed for every relative homogeneous vegetation community (Van der Westhuizen et al., 1999; Van der Westhuizen, 2003; Van der Westhuizen et al., 2005; Van der Westhuizen \& Snyman, 2011a). Rangeland condition was further divided into five classes ranging from very poor

Table 1. Homogeneous vegetation types, climate and dominant soil forms.

\begin{tabular}{|c|c|c|c|c|c|c|}
\hline \multirow[t]{2}{*}{ Vegetation types* } & \multirow{2}{*}{$\begin{array}{l}\text { Rainfall } \\
(\mathrm{mm})\end{array}$} & \multicolumn{2}{|c|}{$\begin{array}{l}\text { Average monthly } \\
\text { temperatures }\left({ }^{\circ} \mathrm{C}\right)\end{array}$} & \multicolumn{3}{|c|}{ Dominant soil types } \\
\hline & & Max. & Min. & SA forms & SA series & WRB \\
\hline Panicum Grassland ${ }^{1}$ & $460-580$ & 30.1 & -1.2 & Arcadia & Arcadia, Gelykvlakte & Pelic Vertisols \\
\hline Themeda-Sporobolus ${ }^{1}$ & $400-525$ & 30.9 & -1.6 & Hutton & Shorrocks & Chromic Luvisols \\
\hline Sandy vegetation south ${ }^{1}$ & $400-490$ & 32.6 & -1.0 & Hutton & Shorrocks & Chromic Lixisols \\
\hline Sandy vegetation north ${ }^{1}$ & $400-490$ & 32.6 & -1.0 & Hutton & Mangano Shorrocks & Chromic Cambisols \\
\hline Eragrostis grass-Karoid ${ }^{2}$ & $320-440$ & 33.7 & 0.1 & Hutton & Mangano & Chromic Regosols \\
\hline Open Parkland north ${ }^{3}$ & $300-400$ & 33.3 & 1.2 & Hutton & Mangano & Chromic Regosols \\
\hline Open Parkland south ${ }^{4}$ & $320-450$ & 32.0 & 0.0 & Hutton & Mangano & Chromic Regosols \\
\hline
\end{tabular}

${ }^{*}$ Semi-arid Grassland biome; ${ }^{2}$ Arid Nama-Karoo biome; ${ }^{3}$ Arid Savannah biome; ${ }^{4}$ Arid transition between Nama-Karoo and Savannah biomes. 
( $\leq 20 \%)$, poor $(21 \%-40 \%)$, moderate $(41 \%-60 \%)$, good $(61 \%-80 \%)$ and excellent $(>80 \%)$. Analysis of variance (ANOVA) was used to test the influence of rangeland condition classes on soil depth. For comparison of means we used the least significant difference (LSD) method with a $p<0.05$ level of significance. A sieve and pipette method (The Non-affiliated Soil Analysis Work Committee, $1990)$ was applied to determine particle size distribution: clay $(<0.002 \mathrm{~mm})$, fine silt $(0.002-0.02 \mathrm{~mm})$, coarse silt $(0.02-0.05 \mathrm{~mm})$, very fine sand $(0.05-0.10$ $\mathrm{mm})$, fine sand $(0.10-0.25 \mathrm{~mm})$, medium sand $(0.25-0.5 \mathrm{~mm})$, and coarse sand $(0.5-2 \mathrm{~mm})$ as indicate in Table 2. Regression analyses were further used to demonstrate the correlation between rangeland conditions and effective soil depth as well as rangeland conditions and soil texture, for some of these homogeneous vegetation communities.

\section{Results and Discussions}

Due to the great variation of soil depth between the different homogenous vegetation communities, soil depth for every site was expressed as a relative value in comparison with the largest soil depth for every farm (Table 3), while basal cover was also expressed as a relative value for every homogeneous vegetation community (Table 3). To quantify the loss in the functioning of the ecosystem in terms of grazing capacity, the relation between rangeland conditions and grazing capacity was used as previously described by Van der Westhuizen et al. (2001), Van der Westhuizen (2003) and Van der Westhuizen and Snyman (2011b). These relations were determined over the long-term (13 years) along degradation gradients for 10 of the 16 homogenous vegetation types (Van der Westhuizen, 2003). Ecosystem functioning for livestock production was further calculated, for this study based on the loss in grazing capacity and livestock numbers in comparison with optimal conditions. The relative livestock numbers according to the grazing capacity for different rangeland conditions in each of

Table 2. Variation in soil particle size distribution (\%) and effective soil depth ( $\mathrm{mm})$ for the different homogeneous vegetation types.

\begin{tabular}{|c|c|c|c|c|c|c|c|}
\hline & $\begin{array}{l}\text { Panicum } \\
\text { Grassland }\end{array}$ & $\begin{array}{l}\text { Themeda- } \\
\text { Sporobolus }\end{array}$ & $\begin{array}{c}\text { Sandy } \\
\text { vegetation south }\end{array}$ & $\begin{array}{c}\text { Sandy } \\
\text { vegetation } \\
\text { north }\end{array}$ & $\begin{array}{c}\text { Eragrostis } \\
\text { grass-Karoid }\end{array}$ & $\begin{array}{c}\text { Open } \\
\text { Parkland } \\
\text { north }\end{array}$ & $\begin{array}{c}\text { Open } \\
\text { Parkland } \\
\text { south }\end{array}$ \\
\hline Clay & $26-44$ & $16-27$ & $14-23$ & $9-26$ & $11-15$ & $8-11$ & $9-11$ \\
\hline Fine silt & $3-6$ & $3-7$ & $2-4$ & $1-4$ & $<9$ & 2 & $1-3$ \\
\hline Coarse silt & $10-19$ & $4-16$ & $4-9$ & $5-16$ & $3-10$ & $1-4$ & $3-4$ \\
\hline Very fine sand & $27-47$ & $13-23$ & $16-22$ & $36-50$ & $37-45$ & $23-25$ & $28-30$ \\
\hline Fine sand & $<10$ & $21-61$ & $43-63$ & $10-24$ & $16-28$ & $55-57$ & $50-52$ \\
\hline Medium sand & $1-6$ & $4-7$ & $4-6$ & $8-15$ & $14-18$ & $7-9$ & $7-8$ \\
\hline Coarse sand & $1-4$ & $<3$ & $<1$ & $1-2$ & $1-3$ & $<1$ & 1 \\
\hline Soil depth & $350-750$ & $630-830$ & $250-800$ & $500-1000$ & $550-880$ & $450-1000$ & $450-1000$ \\
\hline
\end{tabular}


Table 3. Relative soil depth, basal cover and ecosystem functioning loss for different rangeland condition classes.

\begin{tabular}{cccc}
\hline Rangeland condition classes & $\begin{array}{c}\text { Relative soil } \\
\text { depth (\%) }\end{array}$ & $\begin{array}{c}\text { Relative basal } \\
\text { cover (\%) }\end{array}$ & $\begin{array}{c}\text { Relative ecosystem } \\
\text { functioning loss (\%) }\end{array}$ \\
\hline Excellent $(>80 \%)$ & $90 \pm 13.9^{\mathrm{a}}$ & $94 \pm 15.4^{\mathrm{a}}$ & $0-6$ \\
Good $(61 \%-80 \%)$ & $84 \pm 21.9^{\mathrm{ab}}$ & $77 \pm 19.3^{\mathrm{b}}$ & $6-23$ \\
Moderate $(41 \%-61 \%)$ & $77 \pm 21.9^{\mathrm{b}}$ & $65 \pm 23.5^{\mathrm{b}}$ & $23-51$ \\
Poor $(21 \%-40 \%)$ & $73 \pm 24.3^{\mathrm{b}}$ & $42 \pm 18.4^{\mathrm{c}}$ & $51-70$ \\
Very poor $(\leq 20 \%)$ & $76 \pm 22.0^{\mathrm{ab}}$ & $39 \pm 17.1^{\mathrm{c}}$ & $>70$ \\
\hline
\end{tabular}

a,b,c,dValues (mean $\pm \mathrm{SD}$ ) within a column followed by different superscript letters are significantly different $(p<0.05)$.

the homogenous vegetation types was calculated using the methodology described by Van der Westhuizen (2003).

Although soil depth can vary greatly over a short distance, statistical analyses revealed a significant difference between relative soil depth and rangeland condition classes, whereby soils of the excellent condition class were significantly deeper $(p<0.05)$ than those of the moderate and poor condition classes. With the exception of the very poor condition class, a clear trend was found between relative soil depth and declining rangeland condition classes, where soil depth declines as rangeland conditions decrease. The larger soil depth in the very poor condition class in comparison with the poor condition class could be probably attributed to the fact that species with low creeping growth forms, predominate in the very poor condition class and includes species such as Cynodon hirsutus, C. dactylon and Sporobolus discosporus. The availability of these species to grazers is low and is very resistant to grazing. Due to stolons and rhizomes these perennials are excellent soil stabilizers and very useful in preventing further soil erosion (Gibbs Russell et al., 1990; Van der Westhuizen et al., 1999; Fouché et al., 2014), while the creeping growth form also protects the soil against animal trampling. Relative basal cover decreased significantly $(p<0.05)$ over the degradation gradients, where relative basal cover for rangeland in excellent condition was significantly higher than rangeland in good and moderate condition, which was significantly higher than rangeland in poor and very poor condition classes (Table 3).

The calculated average loss in the functioning of the grazing ecosystem for livestock production, was striking. Although the relation between rangeland condition and grazing capacity will vary between the different homogeneous vegetation types, the functioning of both the plant communities and soil is crucial for sustainable ecosystem functioning. Some consistent differences remained for effective soil depth; soil texture and plant cover over degradation gradients as outlined for a few homogeneous vegetation communities below. For these few relative homogeneous vegetation communities, soil depth was more sensitive to rangeland condition, and they vary from the clayey soils of the floodplains of 
rivers to the more deeply sandy soils.

\subsection{Homogeneous Vegetation Communities}

\subsubsection{Panicum Grassland of the Floodplains of the Vet and Sand Rivers}

This area comprised the flood plains all along the riverbeds of the Vet and Sand rivers (Figure 1), a distance of about $110 \mathrm{~km}$ starting in the east at the Allemanskraal and Erfenis dams and ending in the west in the magisterial district of the town Hoopstad. This homogeneous vegetation community plays a major role in the catchment area of Bloemhof dam. Soils can be classified as Vertisols (WRB, 2007), with a high clay content, and mean annual rainfall varies between 460 $\mathrm{mm}$ in the west to $580 \mathrm{~mm}$ in the east (Table 1) with a standard deviation of more than $135 \mathrm{~mm}$. Vegetation is classified as sweet grassland with Panicum coloratum dominating when it is in an ecologically stable condition. Setaria spacelata can also be abundant while relatively dense stands of Vachellia karoo trees and a sparse growth of karoo shrubs also occur. With rangeland degradation the highly palatable $P$. coloratum will decline mainly at the expense of the unpalatable Aristida bipartita, while the creeping growth form grass Sporobolus discosporus will dominate on trampled and overgrazed rangeland (Van der Westhuizen, 2003).

Relation between rangeland conditions and basal cover, soil depth (Table 4) and soil texture (Table 5) was identified for this relatively homogeneous vegetation community. The clay fraction decreased over the degradation gradient, while the total sand fraction increased with rangeland degradation. This could probably be explained by the high clay and silt fractions of the Vertisols. Clay-sized sediment, because of its very small size, is more susceptible to surface runoff in either the suspended or attached form when topsoil texture changes from clay to sandy clay loam. The loss of soil depth and the clay sediment due to

Table 4. Vegetation, soil depth and ecosystem functioning changes over the degradation gradient for the Panicum Grassland of the floodplains of the Vet and Sand rivers.

\begin{tabular}{cccccc}
\hline $\begin{array}{c}\text { Rangeland } \\
\text { condition } \\
(\%)\end{array}$ & $\begin{array}{c}\text { Dominant } \\
\text { plant specie }\end{array}$ & $\begin{array}{c}\text { Basel } \\
\text { cover } \\
(\%)\end{array}$ & $\begin{array}{c}\text { Soil } \\
\text { depth } \\
(\mathrm{mm})\end{array}$ & $\begin{array}{c}\text { Grazing } \\
\text { capacity (ha } \\
\left.\text { LSU }^{-1}\right)^{*}\end{array}$ & $\begin{array}{c}\text { Loss in } \\
\text { ecosystem } \\
\text { functioning (\%) }\end{array}$ \\
\hline 78 & P. coloratum & 7.2 & 710 & 5.4 & 0 \\
70 & P. coloratum & 6.6 & 650 & 5.4 & 0 \\
60 & P. coloratum & 5.8 & 590 & 5.5 & 2 \\
50 & P. coloratum & 5.0 & 530 & 6.0 & 10 \\
40 & P. coloratum & 4.2 & 470 & 9.7 & 44 \\
30 & S. discosporus & 3.3 & 420 & 37.9 & 86 \\
26 & S. discosporus & 3.0 & 400 & 77.5 & 93 \\
$\mathrm{R}^{2}$ & & 0.882 & 0.715 & &
\end{tabular}

*According to Van der Westhuizen (2003). 
Table 5. Soil texture changes in (\%) over the degradation gradients (RC-Rangeland condition).

\begin{tabular}{|c|c|c|c|c|c|c|c|c|c|c|c|}
\hline \multirow[t]{2}{*}{ RC (\%) } & \multicolumn{2}{|c|}{$\begin{array}{l}\text { Panicum } \\
\text { Grassland }\end{array}$} & \multicolumn{2}{|c|}{$\begin{array}{l}\text { Themeda- } \\
\text { Sporobolus }\end{array}$} & \multicolumn{2}{|c|}{$\begin{array}{c}\text { Sandy vegetation } \\
\text { north }\end{array}$} & \multirow{2}{*}{$\begin{array}{c}\text { Eragrostis } \\
\text { grass-Karoid }\end{array}$} & \multicolumn{2}{|c|}{$\begin{array}{c}\text { Open Parkland } \\
\text { north }\end{array}$} & \multicolumn{2}{|c|}{ Open Parkland south } \\
\hline & Clay & Sand & Clay & Sand & Clay & Sand & & Clay & Sand & Clay \& fine Silt & Sand \\
\hline 100 & & & 18 & 76 & 11 & 79 & & 9 & 90 & & \\
\hline 90 & & & 19 & 75 & 11 & 79 & & 9 & 89 & 12 & 87 \\
\hline 80 & 43 & 30 & 21 & 71 & 11 & 79 & & 9 & 89 & 11 & 87 \\
\hline 70 & 39 & 39 & 23 & 66 & 11 & 79 & 19 & 10 & 88 & 11 & 88 \\
\hline 60 & 34 & 48 & 25 & 59 & 11 & 79 & 17 & 10 & 88 & 11 & 88 \\
\hline 50 & 31 & 54 & 26 & 51 & 11 & 79 & 15 & 10 & 88 & 11 & 88 \\
\hline 40 & 29 & 56 & & & 11 & 79 & 13 & 10 & 87 & 10 & 88 \\
\hline 30 & 27 & 56 & & & 11 & 79 & 12 & 11 & 87 & 10 & 89 \\
\hline 20 & & & & & 11 & 79 & & 11 & 86 & 10 & 90 \\
\hline 10 & & & & & 11 & 79 & & 11 & 86 & & \\
\hline 0 & & & & & 26 & 57 & & & & & \\
\hline $\mathrm{R}^{2}$ & 0.96 & 0.98 & 0.81 & 0.94 & 0.97 & 0.89 & 0.53 & 0.67 & 0.99 & 0.99 & 0.97 \\
\hline
\end{tabular}

unsustainable grazing practices, which reduce plant cover, may also be an important mechanism leading to loss of nutrient content and water quality, reducing sustainability of irrigation schemes along-side these rivers and the Bloemhof dam. The calculated loss in the functioning of the ecosystem is also striking with a loss of $44 \%$ at a rangeland condition of $40 \%$ (Table 4 ). Although the highly palatable $P$. coloratum can still be the dominant species, its composition reduces from $72 \%$ to $24 \%$ in comparison with optimum rangeland conditions, while the unpalatable $A$. bipartita and the karoo shrub Felicia muricata also increase at the expense of P. coloratum (Van der Westhuizen, 2003). The estimated loss in ecosystem functioning increased further to more than $85 \%$ when the creeping growth form grass, $S$. discosporus started to dominate if rangeland deteriorates to poor with a rangeland condition of $30 \%$.

\subsubsection{Themeda-Sporobolus Grassland}

This relatively homogeneous vegetation community is covered by the largest parts of the magisterial district of Bultfontein, the western parts of the magisterial district of Brandfort and smaller parts of Boshof district (Figure 1). The area varies from $1250 \mathrm{~m}$ in the western parts to $1420 \mathrm{~m}$ above sea level in the east. The occurrence of big endorheic basins (pans) is characteristic of this area. Mean annual rainfall varies from $400-525 \mathrm{~mm}$ with a standard variation of more than $135 \mathrm{~mm}$. The dominant soil form for the area is Luvisols (Table 1) with more than $15 \%$ clay. Vegetation can be described as sweet grassland where Themeda triandra dominate and is therefore still in optimum condition. However, with degradation the stable perennial grass cover decline as the result of injudicious 
rangeland management. The original grassland will then be largely replaced by Karoo-like vegetation (Van der Westhuizen, 2003).

A relation between effective soil depth and rangeland conditions, as well as basal cover (Table 6), soil texture and rangeland condition (Table 5) was identified. The consequence of the degradation of the natural grass cover, which led to the dominance of karoo shrubs, results in a decline in the grazing capacity as well as a loss in the ecosystem's ability to produce livestock sustainably. Rangeland conditions of $70 \%$ and higher, where the highly desirable T. triandra dominate, is relatively stable in terms of ecosystem functioning. The ecosystem functioning however started to decline at a condition of $60 \%$. Although C. hirsutus started to dominate, perennial grasses such as T. triandra and Eragrostis spp. are still abundant at this condition class. The estimated loss in ecosystem functioning increased further to more than $40 \%$ when karoo shrubs started to dominate when rangeland deteriorates to conditions of $50 \%$ and lower. Grazing capacity will also decline from $6.2 \mathrm{ha} \cdot \mathrm{LSU}^{-1}$ to $11.3 \mathrm{ha} \cdot \mathrm{LSU}^{-1}$ and even lower (Table 6). As the sparse plant cover of karoo shrubs cannot give the soil adequate protection, soil loss and soil compaction increased, leading to a loss in soil depth. An association between soil erosion, soil compaction and effective soil depth was also found by Jordaan (1997) as rangeland deteriorate in the Western Grassland Biome of South Africa. In contrast with the Panicum Grassland of the floodplains of the Vet and Sand rivers, the sand fraction, especially the fine fraction of the topsoil is removed, while the more clayey fraction of the soils remains.

\subsubsection{Southern Variation of Sandy Vegetation of the Western Free State}

This homogeneous vegetation community is situated south of the Modder River in the largest part of the magisterial district of the town Petrusburg, as well as the western parts of Bloemfontein (Figure 1). Soils can be classified as Lixisols (WRB, 2007). The area varies from $1250 \mathrm{~m}$ in the western parts to $1360 \mathrm{~m}$ above

Table 6. Vegetation, soil depth and ecosystem functioning changes over the degradation gradient for the Themeda-Sporobolus Grassland.

\begin{tabular}{cccccc}
\hline $\begin{array}{c}\text { Rangeland } \\
\text { condition (\%) }\end{array}$ & $\begin{array}{c}\text { Dominant plant } \\
\text { specie }\end{array}$ & $\begin{array}{c}\text { Basel cover } \\
(\%)\end{array}$ & $\begin{array}{c}\text { Soil depth } \\
(\mathrm{mm})\end{array}$ & $\begin{array}{c}\text { Grazing capacity } \\
\left(\text { ha LSU }^{-1}\right)^{*}\end{array}$ & $\begin{array}{c}\text { Loss in ecosystem } \\
\text { functioning (\%) }\end{array}$ \\
\hline 96 & T. triandra & 7.8 & 790 & 6.2 & 0 \\
90 & T. triandra & 6.9 & 770 & 6.2 & 2 \\
80 & T. triandra & 5.6 & 740 & 6.3 & 3 \\
70 & T. triandra & 4.6 & 700 & 6.4 & 7.3 \\
60 & C. hirsutus & 3.7 & 670 & 11.3 & 45 \\
50 & Karoo shrubs & 3.0 & 640 & 15.0 & 59 \\
45 & Karoo shrubs & 2.7 & 630 & & \\
\hline
\end{tabular}

${ }^{\star}$ According to Van der Westhuizen (2003). 
sea level in the east with a mean annual rainfall of $400 \mathrm{~mm}$ to $490 \mathrm{~mm}$ (Table 1). Vegetation can be described as semi-arid, sweet grassland where the palatable $T$. triandra dominate in an optimum condition. With rangeland degradation $T$. triandra is firstly replaced by Digitaria eriantha as dominant species, while Aristida congesta can also increase at the expense of both $T$. triandra and $D$. eriantha. Rangeland in a poor to very poor condition is dominated by Cynodon hirsutus (Van der Westhuizen, 2003).

No relation could be found between rangeland condition and soil texture. The texture of topsoils of this plant community is sandy loam with a total sand fraction of about $75 \%$ of which the fine sand fraction contributes about $50 \%$ (Table 2). Because soil texture did not change over the degradation gradient, it could be an indicator that soil compaction over the long-term is the main contributor to loss in soil depth for this homogeneous vegetation community. Relations between rangeland condition and soil depth as well as rangeland condition and basal cover were identified (Table 7). As rangeland deteriorated to a condition of $50 \%$, the palatable $D$. eriantha will replace $T$. triandra as dominant species, basal cover will decline, leading to a decline in soil depth with a $32 \%$ loss in the functioning of the ecosystem which is unable to sustain livestock. With further degradation the occurrence of $D$. eriantha and $T$. triandra will decline even more, at the expense of $C$. hirsutus, while $A$. congesta can also increase, resulting in a further decline in basal cover, soil depth and ecosystem functioning.

\subsubsection{Northern Variation of Sandy Vegetation of the Western Free State}

This relative homogeneous plant community is situated just south of the

Table 7. Vegetation, soil depth and ecosystem functioning changes over the degradation gradient for the Southern variation of sandy vegetation of the western Free State.

\begin{tabular}{cccccc}
\hline $\begin{array}{c}\text { Rangeland } \\
\text { condition } \\
(\%)\end{array}$ & $\begin{array}{c}\text { Dominant } \\
\text { plant specie }\end{array}$ & $\begin{array}{c}\text { Basel } \\
\text { cover (\%) }\end{array}$ & $\begin{array}{c}\text { Soil } \\
\text { depth (mm) }\end{array}$ & $\begin{array}{c}\text { Grazing } \\
\text { capacity } \\
\text { (ha.LSU-1 })^{*}\end{array}$ & $\begin{array}{c}\text { Loss in } \\
\text { ecosystem } \\
\text { functioning (\%) }\end{array}$ \\
\hline 87 & T. triandra & 7.5 & 660 & 5.8 & 2 \\
80 & T. triandra & 7.2 & 620 & 6.0 & 5 \\
70 & T. triandra & 6.8 & 560 & 6.4 & 11 \\
60 & T. triandra & 6.4 & 510 & 7.2 & 21 \\
50 & D. eriantha & 6.0 & 460 & 8.4 & 32 \\
40 & D. eriantha & 5.7 & 420 & 10.3 & 56 \\
30 & C. hirsutus & 5.4 & 380 & 13.0 & \\
20 & C. hirsutus & 5.1 & 340 & & \\
10 & C. hirsutus & 4.8 & 310 & & \\
2 & C. hirsutus & 4.5 & 290 & & \\
$\mathrm{R}^{2}$ & & 0.638 & 0.667 & & \\
\hline
\end{tabular}

*According to Van der Westhuizen (2003). 
Themeda-Sporobolus Grassveld of the endorheic basins (pans) and occurs in a portion of the Boshof magisterial district, as well as the western parts of Brandfort (Figure 1). The area is generally lower lying $(1240-1340 \mathrm{~m})$ and rainfall and soil forms coincide with the southern variation of the sandy vegetation of the western Free State. However, soils are usually deeper with less clay in the topsoils, with very fine sand dominant compared to the fine sand in the southern variation.

Vegetation is sweet grassland and in a good-to-excellent condition, dominated by Anthephora pubescens and T. triandra (Van der Westhuizen, 2003). With unsustainable rangeland practices $A$. pubescens and $T$. triandra will firstly be replaced by Elionurus muticus and $A$. congesta and lastly by Cynodon species. Overgrazing is, however, not the only cause of rangeland retrogression in this area, as selective grazing also contributes to degradation. According to Opperman et al. (1974) and Snyman (2015), the unpalatable E. muticus causes more selective grazing problems in South Africa than any other single species. It occurs in 34 of the 70 main veld types of South Africa (Acocks, 1988) and is associated more with sandy soils of sour grassland vegetation types. Number of grazing camps and long growing season rests are management strategies that can restore degraded rangeland, due to selective grazing (Van der Westhuizen et al., 2005).

It seems, however, that this vegetation type has a good resistance to a decline in soil depth and the only deviation in soil depth (Table 8 ) as well as soil texture was measured at the poorest rangeland condition site over the degradation gradient (Table 5). As this site was dominated with $A$. congesta (37\%), with very few and shallow roots, as well as the fact that basal cover was reduced to only $2.4 \%$ could probably be an explanation in comparison with rangeland condition of 10\%, where species such as Eragrostis lehmanniana and even T. triandra still occur. Unfortunately, the relation between grazing capacity and rangeland conditions was not previously determined for this vegetation type and the loss in ecosystem functioning could therefore not be calculated.

\subsubsection{Eragrostis Grass-Karoid Vegetation}

This relatively homogeneous plant community occurs in parts of Koffiefontein, Fauresmith and Jacobsdal magisterial districts (Figure 1). It also extends over the Northern Cape border and occurs in the Barkley West district as well as smaller parts of the Herbert district. The mean annual rainfall is lower than the previously described homogeneous vegetation types and varies from $320 \mathrm{~mm}$ in the west to $440 \mathrm{~mm}$ in the east. Soils can be classified as Regosols (Table 1).

Vegetation can be described as an arid Nama-Karoo environment (Mucina \& Rutherford, 2006) and consists of a mixture of grasses and karoo shrubs. Vegetation is dominated by the perennial grass (Eragrostis lehmanniana) that establishes between the karoo shrubs. With rangeland degradation the contribution of perennial grasses declines, while unpalatable karoo shrubs remain and the rangeland will also lose basal cover that is critical for the maintenance of soil depth, resulting in a loss in ecosystem functioning of more than 40\% (Table 9). 
Table 8. Vegetation and soil depth changes over the degradation gradient for the Northern variation of sandy vegetation of the western Free State.

\begin{tabular}{|c|c|c|c|}
\hline Rangeland condition (\%) & Dominant plant specie & Basel cover (\%) & Soil depth (mm) \\
\hline 100 & A. pubescens & 8.4 & 1000 \\
\hline 90 & $\begin{array}{c}\text { A. pubescens } \\
\text { E. muticus }\end{array}$ & 7.3 & 1000 \\
\hline 80 & $\begin{array}{l}\text { T. triandra } \\
\text { E. muticus }\end{array}$ & 6.4 & 1000 \\
\hline 70 & $\begin{array}{c}\text { T. triandra } \\
\text { E. muticus } \\
\text { T. koelerioides }\end{array}$ & 5.5 & 1000 \\
\hline 60 & $\begin{array}{c}\text { E. muticus } \\
\text { T. triandra }\end{array}$ & 4.8 & 1000 \\
\hline 50 & $\begin{array}{l}\text { E. muticus } \\
\text { A. congesta }\end{array}$ & 4.2 & 1000 \\
\hline 40 & A. congesta & 3.6 & 1000 \\
\hline 30 & A. congesta & 3.2 & 1000 \\
\hline 20 & A. congesta & 2.7 & 1000 \\
\hline 10 & $\begin{array}{c}\text { Cynodon spp. } \\
\text { A. congesta }\end{array}$ & 2.4 & 1000 \\
\hline 0 & $\begin{array}{c}\text { Cynodon spp. } \\
\text { A. congesta }\end{array}$ & 2.1 & 440 \\
\hline $\mathrm{R}^{2}$ & & 0.504 & 0.691 \\
\hline
\end{tabular}

${ }^{\star}$ Increase due to selective grazing.

Table 9. Vegetation, soil depth and ecosystem functioning changes over the degradation gradient for the Eragrostis grass-Karoid vegetation.

\begin{tabular}{cccccc}
\hline $\begin{array}{c}\text { Rangeland } \\
\text { condition } \\
(\%)\end{array}$ & $\begin{array}{c}\text { Dominant } \\
\text { plant specie }\end{array}$ & $\begin{array}{c}\text { Basel } \\
\text { cover } \\
(\%)\end{array}$ & $\begin{array}{c}\text { Soil depth } \\
(\mathrm{mm})\end{array}$ & $\begin{array}{c}\text { Grazing } \\
\text { capacity } \\
(\text { ha·LSU }\end{array}$ & $\begin{array}{c}\text { Loss in } \\
\text { ecosystem }\end{array}$ \\
\hline 71 & E. lehmanniana & 2.6 & 850 & 20.5 & 21 \\
70 & E. lehmanniana & 2.5 & 840 & 20.7 & 22 \\
60 & E. lehmanniana & 1.9 & 760 & 23.5 & 31 \\
50 & Karoo shrubs & 1.4 & 690 & 27.9 & 42 \\
40 & Karoo shrubs & 1.0 & 620 & 36.3 & 55 \\
30 & Karoo shrubs & 0.6 & 560 & & \\
27 & Karoo shrubs & 0.5 & 550 & & \\
$\mathrm{R}^{2}$ & & 0.608 & 0.963 & & \\
\hline
\end{tabular}

* According to Van der Westhuizen (2003).

As data was collected over degradation gradients in the same paddock on every farm, it is clear that this increase in karoo shrubs over grazing gradients is not due to the changes in rainfall patterns, but due to increasing grazing pressure, as 
the rangeland deteriorates.

In addition, no change in the clay fraction was found. However, particles with a diameter $<0.02 \mathrm{~mm}$ (silt and fine clay) decline from $19 \%$ to $11 \%$ over the degradation gradient (Table 5). The dominant particle size fraction is very fine sand $(0.05-0.10 \mathrm{~mm}$ ) (Table 2), which accounted for $42 \%$ - 37\% over the degradation gradient. With rangeland degradation, the fine sand $(0.10-0.25 \mathrm{~mm})$ increased from $17 \%$ to $28 \%$ and very fine sand $(0.05-0.10 \mathrm{~mm})$ also declined. This data corresponds with data of $\mathrm{Li}$ et al. (2009) who find a decline in particles < $0.125 \mathrm{~mm}$ with wind erosion over two seasons in an arid environment in Mexico. Due to the low rainfall and poor soil structure, these sandy loam to loamy sand soils are highly susceptible to wind erosion, indicating that wind erosion is more important than water erosion in this arid environment. According to Holmes et al. (2008), wind erosion is predominant in the western Free State of South Africa and research conducted indicates that this type of land degradation has reached alarming levels.

\subsubsection{Northern Variation of the Open Parkland}

This relatively homogeneous vegetation occurs in the magisterial districts of Boshof and the northern parts of Jacobsdal (Figure 1). It also extends over the Northern Cape Province border and occurs in the magisterial district of Kimberley. The Modder River valley divides the Open Parkland into a northern and southern variation. The average annual rainfall varies from $300 \mathrm{~mm}$ to $400 \mathrm{~mm}$ (Table 1), almost $80 \%$ falling during the six months of November to April. The soils consist of Kalahari sand on limestone and are classified as Regosols (WRB, 2007) with less than $12 \%$ clay.

Vegetation can be described as parkland with scattered thorn trees of which Vachellia tortilis and V. erioloba are the most characteristic. According to $\mathrm{Mu}-$ cina and Rutherford (2006) it forms part of the Savannah biome. Where the rangeland is well managed, the palatable perennial grass Schmidtia pappophoroides still dominates. As rangeland degrades due to unsustainable grazing practices, $S$. pappohoroides will firstly be replaced by E. lehmanniana, followed by $A$. congesta and lastly by both $C$. hirsutus and $C$. dactylon (Van der Westhuizen, 2014). This change in species composition over the grazing gradient is due to the increase in grazing pressure.

A relation between effective soil depth and rangeland condition exists as soil depth declines from $1000 \mathrm{~mm}$ to $450 \mathrm{~mm}$ over the degradation gradient (Table 10). However, soil texture changes little over the degradation gradient (Table 5), indicating that long-term soil compaction could play a major role in determining effective soil depth. Unfortunately, not enough data in terms of basal cover and grazing capacity was available to confirm this deduction for this vegetation type.

\subsubsection{Southern Variation of the Open Parkland}

Deep sandy soils on limestone characterizes the southern variation that has soils 
Table 10. Vegetation and soil depth changes over the degradation gradient for the Open Parkland.

\begin{tabular}{ccccc}
\hline \multirow{2}{*}{$\begin{array}{c}\text { Rangeland } \\
\text { condition (\%) }\end{array}$} & $\begin{array}{c}\text { Nominant plant } \\
\text { specie }\end{array}$ & $\begin{array}{c}\text { Soil depth } \\
(\mathrm{mm})\end{array}$ & $\begin{array}{c}\text { Dominant plant } \\
\text { specie }\end{array}$ & $\begin{array}{c}\text { Soil depth } \\
(\mathrm{mm})\end{array}$ \\
\cline { 2 - 5 } 100 & S. pappophoroides & 1010 & & \\
90 & S. pappophoroides & 980 & E. lehmanniana & 1000 \\
80 & S. pappophoroides & 950 & E. lehmanniana & 1000 \\
70 & E. lehmanniana & 920 & E. lehmanniana & 1000 \\
60 & E. lehmanniana & 870 & E. lehmanniana & 1000 \\
50 & A. congesta & 820 & E. lehmanniana & 880 \\
40 & A. congesta & 760 & Cynodon spp. & 740 \\
30 & Cynodon spp. & 680 & Cynodon spp. & 580 \\
20 & Cynodon spp. & 570 & Cynodon spp. & 480 \\
13 & Cynodon spp. & 450 & & \\
$\mathrm{R}^{2}$ & & 0.998 & & 0.972 \\
\hline
\end{tabular}

with less than $12 \%$ clay and more than $86 \%$ sand, occurring in the western parts of Petrusburg district, the eastern parts of Jacobsdal and Koffiefontein and smaller parts of Fauresmith magisterial districts (Figure 1). The vegetation can be described as a transitional stage between the Savannah biome and the Nama-Karoo biome. As previously described, the area is separate from the northern variation of the Open Parkland by the Modder River valley. The average annual rainfall varies from $320 \mathrm{~mm}$ to $450 \mathrm{~mm}$ (Table 1). However, there is lesser occurrence of trees, compared with the northern variation and the vegetation is dominated by perennial grasses.

Effective soil depth and rangeland condition is related as soil depth declines from $1000 \mathrm{~mm}$ to $480 \mathrm{~mm}$ over the degradation gradient (Table 10). This loss in effective soil depth compares with the northern variation of the Open Parkland. A small change in soil texture as manifested in the different particle size fractions was also found over the degradation gradient (Table 5), where silt-plus-fine clay fractions $(<0.02 \mathrm{~mm})$ decline by $2 \%$ as rangeland degraded, while a small increase in the sand fraction $(0.05-2.00 \mathrm{~mm})$ occurred. Insufficient data in terms of basal cover and grazing capacity was available to draw a conclusion for this vegetation type.

\subsection{Soil and Vegetation Attributes}

The results of this study showed distinct effects of rangeland conditions on effective soil depth, vegetation cover and soil texture. These results also vary over different relative homogeneous vegetation communities, and pertinent aspects of soil depth, soil texture and vegetation cover will be elucidated to provide a better 
perspective.

\subsubsection{Soil Depth}

Although many studies in the past focused on issues such as soil compaction, bulk density and soil erosion losses on rangeland, relations between effective soil depth and rangeland condition were not yet quantified. In arid and semi-arid environments of the Free State province of South Africa, a significant difference in effective soil depth over degradation gradients occurred on 41 farms. Effective soil depth of rangelands in a poor condition is on average about $17 \%$ less when compared with rangeland in excellent condition. Soil loss is inversely proportional to vegetation cover (Table 3 ). The effects of rangeland conditions and basal cover on the relative loss of soil depths showed for seven different homogeneous vegetation types that the effect of the loss in soil depth was more sensitive over the degradation gradients. Soil depth decreases as rangeland conditions and basal cover decline, particularly in these arid and semi-arid environments where basal cover is relatively low.

It seems, however, that vegetation with deep sandy soils and a clay fraction of less than $15 \%$ are more at risk for soil depth loss. The soil depth decline for these vegetation communities was more than $50 \%$, over the degradation gradients. Wind erosion is predominant in the western Free State and has reached alarming levels (Holmes et al., 2008). Furthermore, sandy soils are characterized by poor structure and a coarse texture, with a low moisture-holding capacity which increases susceptibility to wind erosion (Hilliard \& Reedyk, 2020). Due to the relatively large spaces between particles, which favour rapid downward water movement, these soils are also easily compacted (Laker \& Nortje, 2020).

\subsubsection{Soil Texture}

Soil texture changes which accompany rangelands deterioration were inconsistent. In the clayey soils of the floodplains of the Vet and Sand rivers, where water sheet erosion plays a major role, the clay fraction declines over the degradation gradient. In the sandy loam soils of the Themeda-Sporobolus grassland as well as the northern variation of the sandy vegetation of the western Free State, the clay fraction increased as the topsoil are removed due to erosion. In the case of Regosols with Eragrostis-grass-Karoid vegetation, wind erosion causes a decline in the clay fraction and an increase in the fine sand fraction. It is also interesting to note that Lixisols with a high sand fraction $(>75 \%)$ of which the fine sand is the dominant fraction (about 50\%), did not change much over the degradation gradient. It seems therefore that the decline of soil depth is mainly due to animal trampling and soil compaction.

\subsubsection{Vegetation Cover}

Vegetation cover is an integrative indicator of the soil's overall quality (Kotzé et al., 2020). Vegetation cover affects the hydrological functioning of soils and is responsible for the infiltration rate of water and the prevention of soil erosion. In arid and semi-arid environments, unsustainable grazing practices, which lead 
to rangeland degradation, will result in a decrease in palatable perennial plants in favour of less palatable, undesirable vegetation (Van der Westhuizen et al., 2005). The intensity of the ground cover is also affected, causing a significant decline in basal cover and hence soil erosion over the degradation gradients. We found a loss in basal cover over degradation gradients on 41 farms, averaging only $42 \%$ in rangelands with poor condition, when rangeland in excellent condition serves as reference (Table 3 ).

The effect of vegetation cover is, however well demonstrated in the ThemedaSporobolus Grassland. This sweet grassland vegetation can degrade to Karoo-like vegetation and is a very good example of False Karoo vegetation encroachment as firstly described by Acocks in 1953 (Acocks 1988). The decrease in palatable grass of $T$. triandra inevitably leads to loss of soil and a consequent reduction in the effectiveness of rainfall. Basal cover declines from $7.8 \%$ to only $3 \%$ (Table 6), a loss of more than $40 \%$ vegetation cover, as rangeland changes from dominant grassland vegetation to Karoo-like vegetation (rangeland condition of $50 \%)$.

Rangeland improvement is a slow process and changes in plant composition and cover are not always reversible, while the time for species turnover is also unknown. Where the topsoil still remains and water infiltration is still good, the rangeland can react to conservation measures and it is possible to reach optimal conditions. It is therefore of the utmost importance, where these conditions still prevail, that all possible measures be taken to restore the palatable perennial vegetation cover before the topsoil is blown, washed or compacted to such an extent that the rangeland loses its ability to support livestock production.

\subsection{Rangeland Ecosystem Functioning}

Rangeland degradation is closely linked to the collapse of ecosystem services such as the provision of grazing (Du Preez et al., 2020). If we do not control the impact of unsustainable grazing practices, we will reduce the capacity of natural rangelands to support livestock production, thereby threatening rural livelihoods and food production. As already mentioned, we used objective long-term relationships between rangeland condition and grazing capacities to calculate the loss in ecosystem functioning.

On average, a loss of more than $50 \%$ in ecosystem functioning was quantified when rangelands degrade to a condition of $40 \%$ and lower (Table 3 ). This process of loss in grazing capacity was most evident in the arid Eragrostis grass-Karoid vegetation. Already at a condition of $70 \%$, the utilizable forage production was $21 \%$ lower (Table 9 ) than optimal conditions. At a rangeland condition of $60 \%$, basal cover declines to less than 2\%. Even at this condition class, the loss in vegetation biodiversity is evident, where the highly productive Cymbopogon pospischilii and highly palatable Panicum stapfianum as well as the drought resistant Stipagrostis obtusa and even the highly palatable karoo shrub Felicia muricata started to disappear from the rangeland (Van der Westhuizen, 2003). This 
leads to an increase in the risk for droughts, while the loss in utilisable fodder production is more than $30 \%$. If the degradation process continues, unpalatable karoo shrubs will begin to dominate the rangeland with a loss of more than $40 \%$ in utilisable livestock production at a rangeland condition of 50\% (Table 9). This loss in ecosystem functioning due to the increase of unpalatable karoo shrubs was also found in the semi-arid Themeda-Sporobolus Grassland. The decline in ecosystem functioning over the degradation gradient was also striking in the Panicum grassland, where the loss in utilizable livestock production was $86 \%$ at a rangeland condition of $30 \%$ in comparison with optimum conditions. When the production potential of this rangeland is overestimated it is clear that the resultant overgrazing will cause a decrease in the palatable $P$. coloratum in favour of the low creeping growth-form $S$. discosporus, with a very low fodder production. The intensity of the ground cover is also affected, resulting in soil erosion and soil compaction, inducing a loss in effective soil depth (Table 4).

As the intention of farmers is firstly to be economically viable, the prevention of degradation of both rangelands and soils is essential to prevent any loss in the ecosystems ability to sustain livestock production. Degradation is however a global concern influencing inter alia hydrological processes, water quality, dust storms, food security, poverty, rural development and the social consequences of uprooted people. The challenge is therefore to transform rangeland management, many of which are still unsustainable into practices that produce food optimally while conserving rangelands. The profitability of the livestock sector could further be drastically increased if sustainable rangeland management practices are implemented for arid and semi-arid environments (Van der Westhuizen et al., 2020).

\section{Conclusion}

This study makes a useful contribution towards the understanding of the dynamics of arid and semi-arid rangelands in South Africa, especially with regard to the negative impact of rangeland degradation on effective soil depth. For the different homogeneous communities investigated, relative soil depth decline from $90 \% \pm 14 \%$ to $73 \% \pm 24 \%$ when rangeland conditions deteriorate from excellent to poor condition classes. The change in rangeland condition classes, as rangeland deteriorated, manifested in a decrease of relative basal cover from $94 \%$ $\pm 15 \%$ to $39 \% \pm 17 \%$, and hence an ecosystem functioning loss of $<6 \%$ to $>70 \%$.

As a consequence of higher grazing pressure over the degradation gradients, degradation of rangelands in arid and semi-arid environments is driven by different vegetation and soil processes: 1) changing of plant species composition where palatable high producing species is replaced by unpalatable or low producing species, 2) decline of vegetation cover, 3) loss in effective soil depth due to soil erosion and soil compaction and 4) changes in the texture of topsoils. This will further lead to a decline in fodder production, grazing capacity and rangeland ecosystem functioning. 
The sensitivity of these degradation processes varies between the different homogeneous vegetation types. The loss in effective soil depth for deep sandy soils, with a clay fraction of less than $15 \%$, declines by more than $50 \%$ as rangeland deteriorates. Soil texture changes were inconsistent for the different homogeneous vegetation types, while the basal cover of the arid Eragrostis grass-Karoid vegetation type declines to less than $1 \%$ as rangeland deteriorates. The calculated loss in ecosystem functioning was also striking, with a loss more than $90 \%$ for the Panicum Grassland of the floodplains of the Vet and Sand rivers.

Consequently, the study highlights the importance of sustainable rangeland management practices to reduce the loss in effective soil depth and to ensure the sustainable utilization of the rangeland ecosystem. As data was collected over a range of different vegetation biomes, different mean annual rainfall conditions and different soil types, it could probably be extrapolated to other arid and semi-arid environments worldwide where the same conditions prevail.

\section{Credit Author Statement}

Van der Westhuizen HC: Conceptualization, Methodology, Validation, Formal analysis, Investigation, Writing-Original draft. Du Preez CC: Methodology, Writing-Review \& Editing. Snyman HA: Methodology, Writing-Review \& Editing.

\section{Acknowledgements}

We express our appreciation to farmers for allowing us to carry out field research on their farms. Special thanks to Piet Goosen, Louis Pansegrouw en Ian Knight for assistance with fieldwork, Dr. Herman Fouché for his over all support of the project, Stefanie Forbs for soil texture analyses, Koos Snyman for assistance with terrain type descriptions and soil texture interpretations and Manuella Lovisa for language editing. This study was funded by the Free State Department of Agriculture and Rural Development with contributions from the University of the Free State.

\section{Conflicts of Interest}

The authors declare no conflicts of interest regarding the publication of this paper.

\section{References}

Abd-Elmabod, S. K., Jordian, A., Fleskens, L., Phillips, J. P., Munoz-Rojas, S., Van der Ploeg, M., Anaya-Romero, M., El-Ashry, S., \& De la Rosa, D. (2017). Modeling Agricultural Suitability along Soil Transects under Current Conditions and Improved Scenario of Soil Factors. In P. Pereira, E. C. Brevik, M. Munoz-Rojas, \& B. A. Miller (Eds.), Soil Mapping and Process Modelling for Sustainable Land Use Management (pp. 193-219). Elsevier. https://doi.org/10.1016/B978-0-12-805200-6.00007-4

Acocks, J. P. H. (1988). Veldtypes of South Africa. Memoirs of the Botanical Survey of 
Southern Africa No. 58. Pretoria: Government Printer.

Adams, K. M. (1996). Influence of Sward Defoliation and Soil Disturbance on Seedling Emergence and Survival in the Southern Tall Grassveld. African Journal of Range \& Forage Science, 13, 131-136. https://doi.org/10.1080/10220119.1996.9647909

Boettinger, J. L., Doolittle, J. A., West, N. E., Bork, E. W., \& Schupp, E. W. (1997). Nondestructive Assessment of Rangeland Soil Depth to Petrocalcic Horizon Using Electromagnetic Induction. Arid Soil Research and Rehabilitation, 11, 375-390. https://doi.org/10.1080/15324989709381490

Chamane, S., Kirkman, K. P., Morris, C. D., \& O’Connor, T. G. (2017). What Are the Long-Term Effects of High-Density, Short-Duration Stocking on the Soils and Vegetation of Mesic Grassland in South Africa? African Journal of Range \& Forage Science, 34, 111-121. https://doi.org/10.2989/10220119.2017.1364295

Du Preez, C. C., Van Huyssteen, C. W., Kotze, E., \& Van Tol, J. J. (2020). Ecosystem Services in Sustainable Food Systems: Operational Definition, Concepts and Applications. In L. Rusinamhodzi (Ed.), The Role of Ecosystem Services in Sustainable Food Systems (pp. 17-42). Cambridge: Academic Press. https://doi.org/10.1016/B978-0-12-816436-5.00002-0

Du Toit, G. V. N. (1986). Die fisiese uitwerking van beweiding deur skape op Karooveld. MSc Agric Dissertation, University of the Free State.

Euckert, D. N., Whigham, T. L., \& Spears, B. M. (1978). Effects of Burning on Infiltration, Sediment and Other Soil Properties in a Mesquite-Tobosagrass Community. Journal of Range Management, 31, 420-425.

Fouché, H. J., Van der Westhuizen, H. C., \& Avenant, P. L. (2014). Grasses of the Kalahari Vegetation Types. Upington: KLK Landbou Beperk.

Gibbs Russell, G. E., Watson, L., Koekemoer, M., Smook, L., Barker, N. P., Anderson, H. M., \& Dallwitz, M. J. (1990). Grasses of Southern Africa. Memoirs of the Botanical Survey of South Africa No 58. Pretoria: Government Printer.

Hilliard, C., \& Reedyk, S. (2020). Soil Texture and Water Quality. Best Management Practices. Government of Canada.

https://agriculture.canada.ca/en/agriculture-and-enviroment/soil-and-land/soil-and-w ater/soil-texture-and-water-quality. Accessed 04.08.21

Holmes, P. J., Bateman, M. D., Thomas, D. S. G., Telfer, M. W., Barker, C. H., \& Lawson, M. P. (2008). A Holocene Late Pleistocene Aeolian Record from Lunette Dunes of the Western Free State Panfield, South Africa. The Holocene, 18, 1193-1205. https://doi.org/10.1177/0959683608095577

Jacobs, L. (1988). Amazing Graze: How the Livestock Industry Is Ruining the American West. United Nations Environmental Program. Desertification Control Bulletin, No. 17, 13-17.

Jordaan, F. P. (1997). Implementation of a Computerised System for Assessing Rangeland Condition and Monitoring in a Number of Key Grazing Areas of the Western Grassland Biome. Ph.D. Thesis, Potchefstroom University for CHE.

Kinucan, R. J., \& Smeins, F. E. (1992). Soil Seed Bank of a Semi-Arid Texas Grassland under Three Longstanding (36-Years) Grazing Regimes. The American Midland Naturalist, 128, 11-21.

Kosmas, C., Kirkby, M., \& Geeson, N. (1999). Manual on Key Indicators of Desertification and Mapping Environmentally Sensitive Areas to Desertification. European Commission, Energy, Environment and Sustainable Development, EUR 18882.

Kotzé, E., Sandhage-Hofmann, A., Meinel, J. A., Du Preez, C. C., \& Amelung, W. (2013). Rangel and Management Impacts on the Properties of Clayey Soils along Grazing Gra- 
dients in the Semi-Arid Grassland Biome of South Africa. Journal of Arid Environments, 97, 220-229. https://doi.org/10.1016/j.jaridenv.2013.07.004

Kotzé, E., Snyman, H. A., \& Du Preez, C. C. (2020). Rangeland Management and Soil Quality in South Africa. In R. Lal, \& B. A. Steward (Eds.), Soil Degradation and Restoration in Africa (pp. 145-170). Boca Raton: CRC Press. https://doi.org/10.1201/b22321-8

Laker, M. C., \& Nortje, G. P. (2020). Review of Existing Knowledge on Subsurface Soil Compaction in South Africa. Advances in Agronomy, 162, 143-197. https://doi.org/10.1016/bs.agron.2020.02.003

Li, J. R., Okin, G. S., \& Epstein, H. E. (2009). Effects of Enhanced Wind Erosion on Surface Soil Texture and Characteristics of Windblown Sediments. Journal of Geophysical Research, 114, 1-8. https://doi.org/10.1029/2008JG000903

Macvicar, C. N., De Villiers, J. M., Loxton, R. F., Verster, E., Lambrechts, J. J. N., Merryweather, F. R., Le Roux, J., Van Rooyen, T. H., Harmse, H. J., \& Von, M. (1977). Soil Classification: A Binomial System for South Africa. Pretoria: Department of Agricultural Technical Services.

Mucina, L., \& Rutherford, M. C. (2006). The Vegetation of South Africa, Lesotho and $S$ waziland. Pretoria: South African National Biodiversity Institute.

Opperman, D. P. J., Roberts, B. R., \& Nel, L. O. (1974). Elionurus argenteus Nees-A Review. Proceedings of the Grassland Society of Southern Africa, 9, 123-131. https://doi.org/10.1080/00725560.1974.9648731

Pietola, L., Horn, R., \& Yli-Halla, M. (2005). Effects of Trampling by Cattle on the Hydraulic and Mechanical Properties of Soil. Soil and Tillage Research, 82, 99-108. https://doi.org/10.1016/j.still.2004.08.004

Pimentel, D., \& Burgess, M. (2013). Soil Erosion Threatens Food Production. Agriculture, 3, 443-463. https://doi.org/10.3390/agriculture3030443

Schenk, H. J., \& Jackson, R. B. (2002). Rooting Depths, Lateral Root Spreads and Below-Ground/Above-Ground Allometries of Plants in Water-Limited Ecosystems. Journal of Ecology, 90, 480-494. https://doi.org/10.1046/j.1365-2745.2002.00682.x

Scotney, D. M., \& McPhee, P. J. (1991). Soil Erosion and Concentration. In F. van Oudtshoorn (Ed.), Guide to Grasses of South Africa (pp. 11-44). Arcadia: Briza Publications.

Smith, H. J. C., Levy, G. L., \& Shainberg, I. (1990). Water-Droplet Energy and Soil Amendments: Effect on Infiltration and Erosion. Soil Science Society of America Journal, 54, 1084-1087. https://doi.org/10.2136/sssaj1990.03615995005400040026x

Snyman, H. A. (2009). Root Studies on Grass Species in a Semi-Arid South Africa along a Degradation Gradient. Agriculture, Ecosystems \& Environment, 130, 100-108. https://doi.org/10.1016/j.agee.2008.12.003

Snyman, H. A. (2014). Gids tot Volhoubare Produksie van Weiding (2nd ed.). Cape Town: Landbouweekblad, Media 24.

Snyman, H. A. (2015). Fire and the Dynamics of Two Unpalatable Grass Species (Cymbopogon pospischilii and Elionurus muticus) in a Semi-Arid Climate. African Journal of Range \& Forage Science, 32, 1-12. https://doi.org/10.2989/10220119.2014.913076

Stavi, I., Ungar, E. D., Lavee, H., \& Sarah, P. (2011). Soil Aggregate Fraction 1-5 mm: An Indicator for Soil Quality in Rangelands. Journal of Arid Environments, 75, 1050-1055. https://doi.org/10.1016/j.jaridenv.2011.04.035

Teague, W. R., Dowhower, S. L., Baker, S. A., Haile, N., Delaune, P. B., \& Conover, D. M. (2011). Grazing Management Impacts on Vegetation, Soil Biota and Soil Chemical, Physical and Hydrological Properties in Tall Grass Prairie. Agriculture, Ecosystems \& 
Environment, 141, 310-322. https://doi.org/10.1016/j.agee.2011.03.009

The Non-affiliated Soil Analysis Work Committee (1990). Handbook of Standard Soil Testing Methods for Advisory Purposes. Pretoria: Soil Science Society of South Africa.

Thompsell, A. (2017). Soil Erosion in Africa: Causes and Efforts to Control. ThoughtCo. https://www.thoughtco.com/soil-erosion-in-africa-43352

Tidmarsh, C. E. M., \& Havenga, C. M. (1955). The Wheel-Point Method of Survey and Measurement of Semi-Open Grasslands and Karroo Vegetation in South Africa. Memoirs of the Botanical Survey of South Africa 29. Pretoria: Government Printer.

Trollope, W. S. W., Trollope, L. A., \& Bosch, O. J. H. (1990). Veld and Pasture Management Terminology in Southern Africa. Journal of the Grassland Society of Southern Africa, 7, 52-61. https://doi.org/10.1080/02566702.1990.9648205

Van der Westhuizen, H. C. (2003). Die gebruik van degradasiegradiënte vir weiveldevaluering in 'n semi-ariede gebied. Ph.D. Thesis, University of the Orange Free State.

Van der Westhuizen, H. C. (2014). Dink nuut oor die bepaling van veldtoestand en weidingkapasiteit. In H. A. Snyman (Ed.), Gids tot Die Volhoubare Produksie van Weiding (2nd ed., pp. 56-71). Cape Town: Landbouweekblad, Media 24.

Van der Westhuizen, H. C., \& Snyman, H. A. (2011a). Assessing Rangeland Condition through a Degradation Gradient for a Semi-Arid South Africa Rangeland. In S. Feldman, G. E. Olivia, \& M. B. Sacido (Eds.), Proceedings of the IX International Rangeland Congress (p. 585). International Rangeland Congress, Rosario, Argentina.

Van der Westhuizen, H. C., \& Snyman, H. A. (2011b). Grazing Capacity Quantification in a Semi-Arid South Africa. In S. Feldman, G. E. Olivia, \& M. B. Sacido (Eds.), Proceedings of the IX International Rangeland Congress (p. 307). International Rangeland Congress, Rosario, Argentina.

Van der Westhuizen, H. C., Mohlapo, T. D., De Klerk, J. D., Majola, S. E., Snyman, H. A., \& Neser, F. W. C. (2020). Reproduction Performance of Beef Cattle before and after Implementing a Sustainable Grazing System in a Semi-Arid Grassland of Southern Africa. South African Journal of Agriculture Extension, 48, 112-121. https://doi.org/10.17159/2413-3221/2020/v48n1a530

Van der Westhuizen, H. C., Snyman, H. A., \& Fouché, H. J. (2005). A Degradation Gradient for the Assessment of Rangeland Condition of a Semi-Arid Sourveld in Southern Africa. African Journal of Range \& Forage Science, 22, 47-58. https://doi.org/10.2989/10220110509485861

Van der Westhuizen, H. C., Snyman, H. A., Van Rensburg, W. L. J., \& Potgieter, J. H. J. (2001). The Quantification of Grazing Capacity from Grazing and Production Values for Forage Species in Semi-Arid Grasslands of Southern Africa. African Journal of Range \& Forage Science, 18, 43-52. https://doi.org/10.2989/10220110109485754

Van der Westhuizen, H. C., Van Rensburg, W. L. J., \& Snyman, H. A. (1999). The Quantification of Rangeland Condition in a Semi-Arid Grassland of Southern Africa. African Journal of Range \& Forage Science, 16, 49-61. https://doi.org/10.2989/10220119909485719

WRB (2007). World Reference Base for Soil Resources 2006: A Framework for International Classification, Correlation and Communication. World Soil Resources Reports No. 103.

Zare, S., Jafari, M., Tavili, A., Abbasi, H., \& Rostanpour, M. (2011). Relationship between Environmental Factors and Plant Distribution in Arid and Semiarid Area (Case Study: Shahriyar Rangelands, Iran). American-Eurasian Journal of Agricultural and Environmental Science, 10, 97-105. 
Zhou, M., Liu, C. Z., Wang, J., Meng, Q. F., Yuan, Y., Ma, X. F., Liu, X. B., Zhu, Y. X., Ding, G. W., Zhang, J. Z., Zeng, X. N., \& Du, W. L. (2020). Soil Aggregates Stability and Storage of Soil Organic Carbon Respond to Cropping Systems on Black Soils of Northeast China. Scientific Reports, 10, Article No. 265.

https://doi.org/10.1038/s41598-019-57193-1

Zhou, Z. C., Gan, Z. T., Shangguan, Z. P., \& Dong, Z. B. (2010). Effects of Grazing on Soil Physical Properties and Soil Erodibility in Semiarid Grassland of the Northern Loess Plateau (China). CATENA, 82, 87-91. https://doi.org/10.1016/j.catena.2010.05.005 